\title{
Buddhism and Cognitive (Neuro)Science: An Uneasy Liaison?
}

\author{
Sebastjan VÖRÖS*
}

\begin{abstract}
The main aim of this article is to shed light on the intricate relationship between Buddhism and science by focusing on what is becoming an increasingly popular area of contact between the two domains, namely the study of consciousness in the field of cognitive (neuro)science. First, three fundamental ways of approaching the relationship between Buddhism and science are outlined: (a) rejection (Buddhism and science are not, and cannot be, compatible); (b) acceptance (Buddhism and science share important commonalities); (c) construction (Buddhism and science are compatible because they have been made compatible in the course of specific historical processes). It is claimed that which of the three stances one takes depends ultimately on how one construes the two parties involved and the nature of their (potential) interaction. To exemplify this, the scope of the discussion is narrowed to the domain of consciousness research and a general overview of some of the main arguments for and against the collaboration between Buddhism and cognitive (neuro)science ("Three Turnings of the Wheel of (Non)Interaction") is provided. Finally, in light of the tentative results of our analysis, a short reflection of some of the most pertinent presuppositions and entailments of different stances towards Buddhism-science dialogue is laid out, with special emphasis on the distinction between construing Buddhism as "living" versus "dead" tradition.
\end{abstract}

Keywords: Buddhism, cross-cultural cognitive science, contemplative science, consciousness studies, religion-science debate, dialogue, integration, construction

\section{Izvleček}

Glavni cilj članka je osvetliti zapleten odnos med budizmom in znanostjo. Problema se lotim tako, da se osredotočim na področje, kjer postaja preplet med omenjenima domenama v zadnjem času vse bolj izrazit, se pravi na področje raziskovanja zavesti. V članku najprej očrtam tri splošne pristope $\mathrm{k}$ odnosu med budizmom in znanostjo: (a) ovržba (budizem in znanost nista in tudi ne moreta biti kompatibilna), (b) sprejemanje (budizem in znanost imata specifične skupne lastnosti) in (c) konstrukcija (budizem in znanost sta kompatibilna, saj sta se povezala v specifičnem historičnem kontekstu). V članku zagovarjam stališče, da je izbira med tremi držami v zadnji instanci odvisna od tega, kako

1 Sebastjan VÖRÖS, PhD, Faculty of Arts, University of Ljubljana, Slovenia. sebastjan.voros[at]ff.uni-lj.si

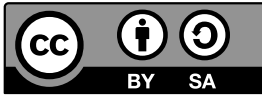


pojmujemo oba akterja in naravo njunega (potencialnega) medsebojnega odnosa. Da bi to lažje ponazoril, diskusijo zožim na polje raziskovanj zavesti in podam splošen pregled ključnih argumentov za sodelovanje med budizmom in kognitivno (nevro)znanostjo (»trije obrati kolesa (ne)sodelovanja«) in tudi proti njemu. Na koncu z upoštevanjem provizoričnih ugotovitev predhodne analize podam še kratko refleksijo o ključnih predpostavkah in posledicah, ki določajo različne drže do dialoga med budizmom in znanostjo, pri čemer poseben poudarek namenim razliki med tem, ali budizem razumemo kot "živo« ali "mrtvo« tradicijo.

Ključne besede: budizem, medkulturna kognitivna znanost, kontemplativna znanost, raziskovanje zavesti, razprave med religijo in znanostjo, dialog, integracija, konstrukcija

\section{Buddhism and Science: Adversaries or Allies?}

The idea of Buddhism as a potential interlocutor and/or ally of science has been around since at least the 19th century. Throughout this period, several points of convergence have been identified, discarded, and sometimes rediscovered (evolutionary theory, cosmology, quantum mechanics, neuroscience), but the main point has remained more or less unaltered: that Buddhism and science are somehow compatible and that by carefully studying their commonalities we might get a better grasp of certain realities they both pertain to. However, the topic in question is notorious for eliciting strong knee-jerk reactions, and is usually met with either ardent enthusiasm or cold disapproval. This is rather unfortunate as it veils the intricacies and complexities of the topic, and thwarts a much needed analysis of some of its most pertinent presuppositions and entailments.

To this end, I propose to get the discursive ball rolling with a famous quote from Albert Einstein:

The religion of the future will be a cosmic religion. It should transcend a personal God and avoid dogmas and theology. Covering both the natural and the spiritual, it should be based on a religious sense arising from the experience of all things, natural and spiritual as a meaningful unity. If there is any religion that would cope with modern scientific needs, it would be Buddhism. (A. Einstein)

There are many things that could be said about this quote, but probably the most important one is that it seems Einstein never actually said it (Lopez 2008, 1-2). This, however, is very telling in itself, and we will use the made-up quote to exemplify three predominant approaches to the Buddhism-Science debate. 
The first approach suggests that the validity of the alleged compatibility between Buddhism and science is tantamount to the validity of the "quote" as a whole: just as Einstein never uttered those words, so too was there never any substantial congruence between Buddhism and science. A sham quote is just that-a sham. It is nothing but the last in a series of sleigh-of-hand attempts to marry two domains that are either incommensurable ("non-overlapping magisteria"; cf. Gould 1999) or epistemically asymmetrical, with one (Buddhism) bound to be reduced to, or explained away by, the other (science) (e.g. Wilson 1998).

The approach on the opposite side of the spectrum sides with the central message of the "quote", maintaining that there is, in fact, a certain kind of "kinship", or at least "compatibility", between Buddhism and science. The precise nature and scope of this compatibility has been a matter of some debate, "with some suggesting that the essential teachings of Buddhism (variously identified) are in no way contradicted by the findings of science (variously enumerated), while others suggest that the Buddha anticipated many of the key discoveries of science" (Lopez 2008,2), but the main contention is that, although perhaps false in attributing the message to the famous physicist, its central point is nevertheless true (Wallace 2002, 2003).

The third approach tries to steer a middle course between the two extremes, suggesting that, although it might be true that (pace first type) there is a certain (sense of) congruence between Buddhism and science, the latter (pace second type) does not necessarily reside "in the things themselves", but is rather a net effect of the historical context in which the discourse of the Buddhism-science dialogue initially emerged. In other words, it is wrong to frame the debate in terms of drawing parallels between two discrete entities ("essences") that may or may not share a certain set of common features; instead, both Buddhism and science must be conceived as (partial or full-blown) historical constructs that have undergone numerous changes governed by a set of specific cultural, social, ideological, etc. factors. According to this view, Buddhism and science do have points in common, because they were made to have certain points in common (Sharf 1995, 2000; Lopez 2008).

In short, there seem to be three basic ways of relating to the introductory make-believe quote and thus of interpreting the relationship between Buddhism and science: (a) rejection: the "quote" is made up and therefore false (i.e. Buddhism and science are not, and cannot be, compatible); (b) acceptance: although falsely attributed to Einstein, its main message holds true (i.e. Buddhism and science are compatible); (c) construction: the "quote" as a whole is neither true nor false, but a side product of a specific historical process (i.e. Buddhism and science are compatible because they have been made compatible). 
The proponents of the idea that there exist relevant commonalities between Buddhism and science (category (b) above) are thus faced with two types of criticism: the first and more straightforward type (category (a) above) claims that all professed similarities are, in the last analysis, illusory: although it might seem that Buddhism and science are compatible, closer scrutiny reveals that this is actually not the case. The second and more subtle type (category (c) above), on the other hand, maintains that, even if professed similarities between Buddhism and science are real (and there are reasons for believing that they might be), upon closer inspection they prove to be very different from what proponents of (b) take them to be. This latter type of critique is especially pertinent because, unlike the blunt categorical dismissal of (a), it is willing to concede that there are (or might be) certain commonalities between Buddhism and science, but is also adamant that this does not necessarily mean that these commonalities tell us anything particularly revealing about the "nature" of Buddhism, science, or their interrelationship.

The main difference between (b) and (c), which both embrace claims of similarity, becomes clearer if we compare two recent books on the topic. Although carrying the same (main) title, the two books differ substantially in their general take on the Buddhism-science dialogue. In his introduction to Buddhism and Science: Breaking the New Ground, the editor Alan Wallace points out that the main presupposition of the book is that Buddhism and science "are commensurable and that the interface between Buddhist theories and practices and scientific theories and models of inquiry can somehow be fruitful" (Wallace 2003 , 1). Wallace is convinced that, once we divorce ourselves from the predominant-cum-reactionary approaches in contemporary academia, which construe Buddhism primarily through the lens of its "textual doctrines", and start paying attention to its "experiential insights", i.e. once we start "entertaining the possibility of learning about the world from Buddhism, as opposed to studying this tradition as a means to learn about Buddhism" (ibid., 27), the way can be paved for "mutually respectful dialogue and collaboration" (ibid., 26). Buddhism, conceived primarily as a repository of various techniques "for the cultivation of contemplative insight", might prove to be of great value to science in general and cognitive science in particular (ibid., 6).

Published just five years later, Buddhism and Science: A Guide for the Perplexed opens with a very different message. The main presupposition of the book is that "in order to understand the conjunction in terms of Buddhism and Science, it is necessary to understand something of the history of the conjunction" (Lopez 2008 , xi). Lopez argues that the origins of this conjunction can be traced back to specific sociocultural circumstances of the (predominantly, but not exclusively) late 19 th and early 20 th century, and were strongly influenced by specific social, 
political, etc. motives (warding off the onslaught of modernism, post-colonialist struggle for independence, etc.): "Asian Buddhists have argued for the compatibility in order to validate their Buddhism. European and American enthusiasts and devotees have argued for the compatibility to exoticize Science, to find it validated in the insights of an ancient Asian sage." (Lopez 2008, 6) In other words, science vested Buddhism with "authority, validation, and truth" (ibid., 32), while Buddhism served as a surrogate and docile form of spirituality, as a "religion that is not a religion", and an "ideal alternative to theism, dogma, and ritual" (ibid., 35). In the course of this complex historical process, both terms have undergone profound changes: Buddhism has come to designate "a single tradition, and within that tradition, an isolated set of elite doctrines and practices", while science seems to have been reduced to little more than "a mantra, a potent sound with no semantic value" (ibid., 32).

The discrepancies between Wallace and Lopez can be readily (re)cast in terms of change vs. construction. While both authors are willing to concede that Buddhism construed as a (potential) partner of science is different from traditional forms of Buddhism that were originally developed in Asian sociocultural contexts, Wallace feels that this "new Buddhism" is basically "Buddhism changed", i.e. that traditional Buddhism has adapted itself to the new environment of the 19th and 20th-century Western world, and Lopez maintains that it is ultimately "Buddhism constructed", i.e. it is a product of complex sociocultural processes that were at work in the period of modernization and (post)colonialism. In short, the question may be posed as follows: is there some relatively stable and/or immutable "aspect" or "dimension" of Buddhism that can be legitimately claimed to be compatible with one or more aspects of science?

One can readily see why issues of this sort can be confusing. They are inseparably connected with the daunting question about the precise nature of Buddhism: Is Buddhism a religion, philosophy, or even science? All three positions have been vigorously defended and just as vigorously attacked. In discussions of this type, one is haunted by the image of (Western) academia perpetually chasing its own tail: one imposes, more or less forcibly, general and vague categories on a complex set of phenomena, and is then surprised when the end result proves to be overgeneralized and vague. Now, there is little doubt that using concepts and categories, such as "religion" and "science", which are not only vague, but were also developed within a specific sociocultural setting with its unique discursive frameworks, to describe phenomena from a radically different sociocultural and discursive background can, and does, lead to confusion and bewilderment. But this can hardly be the whole story. Note that both Wallace and Lopez emphasize the importance of recognizing and tackling problems associated with the cultural specificity of these 
terms, but, curiously enough, they end up with diametrically opposed conclusions. It would seem, then, that the question cannot be solved with the all too often rhetorically florid, but argumentatively vacuous, trope of intercultural incommensurability. Deeper issues might be at stake, and it is this that we would like to focus on in the rest of our paper.

But since all (theoretical) work and no (concrete) play makes Jack a dull boy, we propose to narrow and specify the topic of our discussion: instead of examining the question about the relationship between Buddhism and science in abstracto, we intend to focus on what currently seems to be its hotbed-cognitive (neuro) science. Every century seems to have its pet scientific revolution, and in the 21st century this role seems to have been taken by neuroscience, as amply illustrated by a host of evocative book titles (Buddha's Brain, The Bodhisattva's Brain, Zen and the Brain, etc.), catchy neologisms (NeuroBuddhism, Skeptical Buddhism, Contemplative Science, etc.), and vivid magazine pictures of robed monks with EEG wires attached to their scalps. In what follows, we will take a look at some of the main arguments for and against the collaboration between Buddhism and cognitive (neuro)science ("Three Turnings of the Wheel of (Non)Interaction"), followed by a short reflection of what the overall discussion has to say about some of the main issues we have brought in this section.

\section{Cognitive (Neuro)Science: Between Brains and Qualia}

Cognitive (neuro)science is an cross-disciplinary study of the mind and its processes, encompassing a wide range of scientific disciplines (philosophy, anthropology, linguistics, psychology, computer science, and neuroscience). Since its inception in the 1950s, it has undergone numerous changes, of which two are particularly relevant for the purposes of our study. The first change is the socalled neuroscientific revolution (Lynch 2009). With the emergence of functional imaging techniques in the 1990s it suddenly became possible to examine the neurobiological underpinnings of a vast array of mental processes, making phenomena that have been traditionally banned from natural sciences amenable to scientific inquiry. Neuroscientific studies have proven of great interest to different scientific disciplines and have produced numerous discoveries; however, it did not take long before first critics started voicing their concerns, arguing that unveiling neurobiological underpinnings of mental processes is not necessarily tantamount to unravelling their secrets. Specifically, issues were raised whether cognitive neuroscience is ever likely to close the notorious "explanatory gap” (Levine 2002), separating neural processes from conscious phenomena (cf. 
Nagel 1974). For the most part, neuroscientific models tended to ignore this so-called "hard problem of consciousness"-the problem of explaining why is it that (neuro)cognitive processes are accompanied by subjective or phenomenal experiences (qualia) (Chalmers 1995) — and opted for the study of the underlying (unconscious) mechanisms.

This brings us to the second shift in cognitive (neuro)science, a shift perhaps not as striking as the first one, but of no less significance. Some philosophers and (neuro)scientists, deeply dissatisfied with predominantly reductionist and/ or functionalist trends in contemporary "(neuro)sciences of the mind", tried to approach the "hard problem" by rekindling the interest in first-person approaches to the study of consciousness. Instead of simply ignoring qualia or explaining them away, the proponents of so-called "experiential turn" in cognitive (neuro) science (Froese 2010; Varela et al. 1991) argue that we should (a) find and/or develop first-person methodologies for a disciplined study of conscious phenomena, and (b) integrate these methodologies into mainstream cognitive (neuro)science (e.g. Gallagher 2003; Varela 1996; Varela and Shear 1999). Searching for appropriate candidates, many authors have turned to phenomenological movement (Husserl, Heidegger, and Merleau-Ponty) and contemplative/meditative wisdom traditions, especially Buddhism (Varela et al. 1991; Vörös 2013, 2014; Thompson 2005).

But how exactly is Buddhism supposed to contribute to consciousness research? It has been suggested that the intricate system of Buddhist meditative practices (e.g., samatha, vipasyanā, mettā, etc.) and phenomenological accounts (as outlined in, e.g., Abhidharma) could help science develop invaluable practical know-how for the study of consciousness and thus shed light on some thorny issues in cognitive (neuro)science. The central idea is eloquently expressed by Thompson:

[C]ertain contemplative traditions-Buddhism most notably, but not exclusively-and certain approaches in cognitive science-the embodied approach and neurophenomenology—are not simply compatible, but mutually informative and enlightening. Through back-and-forth circulation, each approach can reshape the other, leading to new conceptual and practical understandings for both. (Thompson 2007, 232)

Put differently, instead of harboring an atmosphere of distrust, cognitive (neuro) science and Buddhism should engage in a reciprocal exchange of know-how and expertise, which might prove mutually illuminative, possibly leading to productive dialogue or even large-scale integration in the form of what has sometimes been called "cross-cultural cognitive science" (Davis and Thompson 2014). 


\section{First Turn of the Wheel: Collaboration}

Before proceeding with some concrete suggestions on how to incorporate Buddhism into cognitive (neuro)science, two caveats are in order. First, in contemporary debates (at least) three points of contact between Buddhism and contemporary cognitive (neuro)science (construed in the broadest possible sense, also encompassing certain psychotherapeutic approaches) have been identified. The idea sketched above, i.e. Buddhism as a potential collaborator of science, is only one among them, the other two being Buddhism as an object of study (mostly related to neuroscientific studies of experienced Buddhist meditators), and Buddhism as a source of alternative/complementary therapeutic (mostly meditation-related) techniques. I have decided to omit these other aspects for two reasons: (i) unlike the first approach, they have both been studied extensively; this is not to say that all issues have been settled — far from it! - but merely that they have been identified by mainstream scientific communities as topics worthy of study (which doesn't necessarily hold true for the first approach); (ii) they are generally less controversial in their claims; again, this is not to say that they are not controversial, but merely that their suggestions concerning the nature of scientific research are not as radical as those put forward by the first proposal. Secondly, to keep the paper within reasonable bounds, our sketch will be somewhat asymmetrical and will focus primarily on what Buddhism might offer cognitive (neuro) science, omitting most references to the opposite question, i.e. what cognitive (neuro)science might offer Buddhism.

Buddhism's contribution to cognitive (neuro)science will be studied under two headings: methodological (improvements of, and/or additions to, scientific knowhow) and thematic (new perspectives on specific topics of inquiry). The two headings are closely related, so I suggest we look at each of them in turn.

\section{Methodological Contributions: Attention Training}

As pointed out above, it has been claimed that rigorous methods are needed for systematic exploration of lived experience. For example, Shear and Jevning speak of a "significant asymmetry" in current neuroscientific studies of consciousness:

For while their objective side employs sophisticated scientific methodologies, capable of isolating and evaluating variables completely outside the ken of ordinary sense perception, their subjective side typically uses mere everyday sorts of introspection, capable of isolating only ordinary internal phenomena such as sense perception, imagining and verbal thought (...) 
The need for systematic first-person methodologies here is thus starkly apparent. (Shear and Jevning 1999, 109)

On a similar note, Francisco Varela, in his groundbreaking paper on neurophenomenology (1996), argues for the need to investigate "the concrete possibilities of a disciplined examination of experience" that would help us combine "cutting edge techniques and analyses from the (neuro)scientific side" with "very consistent development of phenomenological investigation" and thereby move "one step closer to bridging the biological mind-experiential gap" (Varela 1996, 335, 343).

Thus, it would seem that, in order to successfully overcome the explanatory gap and establish a "science of consciousness" proper (if there, indeed, be such a beast!), we must develop and "calibrate" an instrument that would enable us to examine states of consciousness with precision and exactness (Wallace 2003, 16). But what might this indispensable instrument of introspection be? Already a century ago, William James, in his classic Principles of Psychology (1890/1950), wrote that "the faculty of voluntarily bringing back a wandering attention, over and over again, is the very root of judgment, character and will", and that to "improve this faculty would be the education par excellence". However, drawing on findings from late 19th-century psychology, which had suggested that attention cannot be sustained for more than a few seconds at a time, he reached a rather grim conclusion that "(n)o one can possibly attend continuously to an object that does not change" (ibid., 424, 420). In other words, the ability to control attention seems to be the key to unlocking the secrets of the mind, but according to James, this key is fickle and imprecise, perhaps incorrigibly so.

Now, contemplative traditions would agree that it is indeed hard to exert control over one's attention, but they are adamant that it is not impossible: attention can be cultivated and therefore improved (Wallace 1999, 180). Put differently, although people "vary in their abilities as observers and reporters of their own mental lives", these abilities can be "enhanced through mental training of attention, emotion, and metacognition", and contemplative/meditative practice is "a vehicle for precisely this sort of cognitive and emotional training" (Thompson 2007, 228):

[J]ust as unaided human vision was found to be an inadequate instrument for examining the moon, planets and stars, Buddhists regard the undisciplined mind as an unreliable instrument for examining mental objects, processes, and the nature of consciousness. Drawing from the experience of earlier Indian contemplatives, the Buddha refined techniques for stabilizing and refining the attention and used them in new ways, much as Galileo improved and utilized the telescope for observing the heavens. (Wallace 1999, 176) 
For example, the Buddhist practice of samatha (literally, quiescence) was designed to counter two major obstacles to attention, namely excitation and laxity, and to engender a serene mental state, characterized by attentional stability and vividness (Wallace 1999, 177). It therefore provides rigorous pragmatic means for the progressive development of sustained attention (e.g., "9 stages", cf. ibid. 1999, 180-4), which is a sine qua non for any type of phenomenological investigation.

\section{Thematic Contributions: Experiential Landscape and the (No-)Self}

Although there are several research topics where Buddhism might contribute to scientific knowledge, we are going to briefly look at only two of them, namely the exploration of the experiential landscape and the study of the (no-)self. Starting with the first topic, we have seen that meditative practices help us cultivate "a capacity for sustained, attentive awareness of the moment-to-moment flux of experience", and could thereby improve our "phenomenologies of subjective experience", i.e. our overall understanding of the ordinary, day-to-day mental phenomena (Thompson 2007, 228-9). However, and even more intriguingly, Buddhist written and verbal accounts abound in descriptions of experiential phenomena that are rarely encountered in our everyday lives. For example, final stages of samatha practice are said to be characterized by an "absence of appearances", where only "sheer awareness, clarity, and joy of the mind" are present (Wallace 1999, 182). Such experiences are interesting not only because of their extraordinariness, but also because Buddhists seem to be univocal that they underlie our everyday (waking) consciousness. And just as biologists try to get a better understanding of a complex biological phenomenon (e.g. a living organism) by looking at its simplest form (e.g. E. coli), so cognitive scientists might learn a lot about consciousness by looking at its most rudimentary representatives (cf. Forman 2007).

Further, Lancaster argues that certain Buddhist texts and practices provide means of experientially accessing what is normally referred to as "preconscious" or "preattentive" cognitive processes: "Put simply, mystical practice seems to entail a shift in the "leading edge" of consciousness such that elements previously obscured (preconscious) enter the clarity of consciousness" (Lancaster 2005, 253). A similar line of thought is taken by Davis and Thompson, who have recently suggested that the Buddhist "five aggregates model (of the mind)" and "Theravāda mindfulness meditation" might shed light on some recent controversies in consciousness studies, particularly the relationship between phenomenal and access consciousness (cf. Block 2008). In short, phenomenal consciousness is the what-is-it-like character of experience, while access consciousness refers to the 
content of an experience that is accessible in working memory, and can be acted on, verbalized, etc. Currently there is no consensus as to how these two categories are interrelated or even if they actually constitute different phenomena. The intricacies of the debate need not concern us here - what is crucial is that Davis and Thompson feel that the question might not be merely theoretical, but susceptible to empirical/experiential investigation. In their view, one of the major shortcomings in contemporary discussions on the topic is that they proceed without considering "the possibility that specific forms of mental training might be able to produce new data about attention and consciousness" (Davis and Thompson 2014, 591). In effect, they suggest that "Theravāda mindfulness meditation might serve as a useful tool for direct (phenomenological) investigation of certain basic levels of consciousness (a fact substantiated by recent studies of its effects on certain cognitive phenomena, cf. ibid. 2014, 593) and thus help address certain issues from a new (empirical) perspective.

The second domain in which cognitive (neuro)science and Buddhism might engage in a fruitful exchange is the problem of the self. It has long been recognized that the notion of a discrete, (semi-)autonomous entity called "the self" is problematic. For example, in an oft-quoted passage, Hume writes:

For my part, when I enter most intimately into what I call myself, I always stumble on some particular perception or other, of heat or cold, light or shade, love or hatred, pain or pleasure. I never can catch myself at any time without a perception, and never can observe anything but a perception. (Hume 1739, book I, part IV, sect. VI)

The currently predominant view in cognitive science accords with this notion, maintaining that the elusive "ego"/"self" is nothing but a beneficial illusion with no independent existence of its own (e.g. Dennett 1991; Metzinger 2003). Mental life is said to consist of a flux of sub-personal mental processes, the sense of self being merely a useful superimposition on this array of unconscious events.

The main problem with this view, however, is that it seems to contradict our everyday experience: although there might be good scientific reasons for the claim that there are no egos/selves, there seem to be equally, if not even more persuasive phenomenological reasons that such entities do, in fact, exist. Buddhism concurs with scientific claims about the non-existence of unified selves, but on different (if complementary) grounds: it claims that it is not only possible to think the non-existence of the self, but to actually enact it, make it an integral part of one's lived experience. The famous Buddhist doctrine of anatman or no-self is thus not put forward merely as a theoretical model, but as an experiential hypothesis, something 
that can be instantiated if a certain set of procedures is followed. This, however, requires strenuous discipline, as "an untrained mind is inevitably deluded over the real nature of mind and consciousness" (Lancaster 2005, 249). It is for this reason that Varela et al. feel the question of the self to be "the meeting ground" of science, philosophy, and meditative/contemplative traditions: "[A]11 reflective traditions in human history (...) have challenged the naïve sense of the self" (Varela et al.1991, 59). And it is the contention of the proponents of Buddhism-(neuro)science collaboration that these different bodies of knowledge might approach the problem from different, yet mutually enlightening perspectives.

\section{Second Turning of the Wheel: Criticism}

Recently the prospect of incorporating Buddhism into cognitive (neuro)science has been challenged on different grounds. First, it has been claimed the idea of a fruitful collaboration between Buddhism and cognitive (neuro)science has been around for approximately two decades, but so far it has failed to produce tangible empirical results (Garfield 2011; Federman 2011). Yet even if we accept that the reason for this is that the idea is recently new, it still remains dubious as to whether meditative practices might enrich our knowledge of consciousness in principle. Consider the so-called "hermeneutic fallacy": "How do you know that by exploring experience with a method you are not, in fact, deforming or even creating what you experience"? (Varela and Shear 1999, 13) Given that "the mere act of attention to one's experience transforms one's experience" (Chalmers 1997, 44), it would seem that by refining attention, we are not, in effect, gaining a better insight into experience, but redefining its very nature and content.

Moreover, it has been emphasized that there is a tendency among advocates of the proposed fusion towards drawing hasty (over)generalizations. For example, even if, prima facie, there seem to be certain telling similarities between the "findings" of cognitive (neuro)science and Buddhism (e.g., about the nature of the self), these must be treated with caution, as it is possible that they are nothing but remarkable coincidences. Referring to Buddhism, Federman writes: "(This is) not to say that Buddhism and cognitive science are in complete disagreement, but that sweeping statements about similarities are misleading." (Federman 2011, 44) What is more, even if it turns out that these similarities are not merely superficial analogies, one might wonder whether they can be put on equal footing: Are "facts" acquired by some form of Buddhist meditation really on a par with "facts" acquired by science? Federman is empathic on this point: "Buddhism can inspire, but the final word is that of science." (ibid., 46) Garfield goes even further, claiming that the 
only "facts" that Buddhism can offer cognitive (neuro)science are those related to "the particular regions of the brain involved in, or transformed, by meditation", whereas its doctrine, meditative techniques, and phenomenology are of little or no use to contemporary science (Garfield 2011, 17). He goes on to argue that, in its 2500-year history, Buddhism has been unable to unearth some very basic cognitive phenomena, which throws a dubious shadow on its role as a potential collaborator of science:

We have no reason to believe that experienced meditators are immune to inattentional blindness, to the Loftus effect, or the monochromicity of the peripheral vision (...) Moreover, none of these effects, each demonstrable in the undergraduate laboratory, are reported in thousands of years of meditative experience or could be deduced a priori from immediate data of experience. (ibid., 23-24)

From this, Garfield concludes not only that "it would be foolish for cognitive science to rely on Buddhist meditation as a source of evidence or rely on Buddhist theory as a substitute for well-confirmed or cognitive theory", but also that "cognitive science may have more to contribute to Buddhism than the other way around", and that Buddhist theorists of mind would do well "to attend to contemporary scientific results concerning the mind” (ibid., 24, 25).

According to Federman, the incongruence between contemplative and experimental "facts" is further exacerbated by a fundamental difference in the background motivation of Buddhism and cognitive (neuro)science. Whereas the prime motivation of the former is ethical and soteriological, the prime motivation of the latter is descriptive and explanatory. The normative stance of Buddhism, in which the ethical is closely intertwined with the factual, is characteristic of pre-modern systems, and is in direct contrast with the supposedly descriptive, value-free orientation of scientific inquiry (Federman 2011, 47, 52).

Sharf takes the critique one step further, claiming that the prospects of Buddhism-(neuro)science collaboration are flawed in principle. He argues that the emphasis on (meditative) experience, i.e. "the very notion that one can separate an unmediated experience from a culturally determined description of that experience", is "a relatively late and distinctively Western invention" (Sharf 2000, 271). More precisely, the idea that Asian traditions, notably Buddhism, are predicated on religious experience and that meditation is a means to induce these experiences can be traced back to "a handful of twentieth century Asian religious leaders and apologists” (e.g. Radharkishnan for the Hindu, Carus and Suzuki for the Buddhist tradition), and was an integral part of an attempt to legitimize the validity 
of their religious traditions and fend off modernist criticism (Sharf 2000, 271-2; 275). Phenomenological renditions of technical terms such as samädhi (trance), vipasyana (insight), etc., are therefore moot, as they project modern categories onto Buddhist notions and neglect the fact that, traditionally, the meaning of such terms was strongly related to "the polemic and ideological context in which Buddhist meditation (was) carried out" (Sharf 1995, 260): they were not so much descriptive as prescriptive, embedded into broader discursive, ideological, and political strategies of their respective traditions.

\section{Third Wheel: Reclaiming the Ground}

How serious are these challenges? Have they irrevocably done away with the prospect of integrating Buddhism into cognitive science? Not necessarily. In what follows, I will try to address these concerns, but in reverse order.

One of the indisputable contributions of historical/textual criticism à la Sharf to the debate on the role and nature of meditative experience and practice has been to (re)instigate the interest in cultural, historical, social, etc. frameworks, in which specific experiences and practices have emerged. All too often, researchers would downplay these factors, drawing hasty analogies and unwarranted conclusions. But it is one thing to emphasize the importance of specific (cultural, etc.) factors, and another to maintain that all other phenomena are either reducible or subservient to them. Thus, although Sharf has done an outstanding job in demonstrating the embeddedness of contemplative experiences in the broader context of "prior ideological commitments", "socioeconomic background", "political agenda", "sectarian affiliation", "education", etc. (ibid., 265), to maintain that this is all there is to such experiences seems dubious and flies in the face of the available textual evidence. It is true that, in studying ancient meditative manuals, one must pay attention not only to their content (e.g. description of various experiential (?) stages on the contemplative path), but also to the context in which they were used (e.g. underlying ideological structures, specific ceremonial settings, etc.) (ibid., 244), but does this mean that we are entitled to completely ignore the former or reduce it to the latter?

Sharf seems to be aware of the implausibility of such a radical view, and allows for meditative experience to be possible in principle (ibid., 245-6; 259-60), yet hastens to add that, even if it were real, traditionally, it was "not considered the goal of the practice, was not deemed doctrinally authoritative, and did not serve as the reference points for (the practitioners') understanding of the path", because of its "ambiguous epistemological status and essentially indeterminate nature" (Sharf 
2000, 272). But note that, at least for the purposes of the present article, it is not important what role certain practices/experiences played in a given historical context, but the fact that such practices/experiences did exist, or at least, that there are good reasons to assume they did. And since there are, indeed, no water-proof a priori objections to this view-since it is possible that they did, do and can take place-, it is a matter of empirical investigation to ascertain, whether and how these experiences could be studied and/or incorporated into the corpus of scientific inquiry.

Does this mean, however, that the role of Buddhism, especially if we take into account the deep intertwinement of fact and value that seems to be characteristic of it, must necessarily be restricted to that of providing science with data for further analysis, as suggested by Federman and Garfield? Again, not necessarily. First of all, just because descriptive and normative aspects are interlaced in Buddhism, it does not mean that, if subjected to a careful historical and textual analysis, they cannot be separated and studied individually (at least to a certain extent). But even more interestingly, active engagement with such questions projects back to, and sheds light on, the fundamental presuppositions underlying our own views of science. Put differently, it forces us to (re)consider the very idea of "scientific inquiry", alongside with some of its central notions, such as "factuality", "objectivity", "subjectivity", "neutrality", etc. The term "science", as Wallace never tires of emphasizing, is not as univocal as we generally assume, and contains elements that are not as "value-free" and "neutral" as we often take them to be. This (re)opens a host of interesting, and potentially productive questions, i.e. whether or not physicalism and reductionism are necessary ingredients of science, whether the construal of objectivism in the sense of gaining knowledge of an independently existing external reality is plausible, etc.

But the possibility of establishing a fruitful dialogue is, of course, not to suggest that meditative know-how and experience ought to be used as substitutes for time-tested scientific methods (empirical research, statistical analysis, etc.), as implied by Garfield. If anything, meditative practices can be seen as potentially useful complements to the currently prevailing research methodology-complements with their own limited scope and circumscribed domain of inquiry (e.g. phenomenological research). For this reason, it is simply wrong to assume that the "experienced meditators" should have detected the cognitive phenomena alluded to above, as there are good reasons to believe that at least some of these phenomena occur on a pre-experiential, unconscious level, and are therefore not susceptible to phenomenological analysis. Garfield, who lumps all these phenomena under the category of "deep phenomenology", seems to be making a "category mistake" in conflating 1st-person with 3rd-person analysis. At this point in research, it is 
simply too early to speculate about what contemplative training cannot do: a much more productive strategy would be to carefully consider which elements might be useful, and then try to systematically test them in a laboratory setting.

But what of the claim that by methodically analyzing experience we are, in fact, changing the experience itself? Here, I am inclined to side with Varela and Shear, who agree that this is "a significant problem" as "every examination is (already) an interpretation", but then go on to add that this does not necessarily mean that a rigorous approach to experience creates nothing but artefacts. Exploration of experience, they claim, is on the same boat as all the other types of scientific investigation: it is bound to suffer from "cultural expectations and instrumental bias", but, at the same time, "there is no evidence that the phenomenal data gathered are not equally constrained by the proper reality of consciousness contents". And even though human experience is not a fixed domain, but is changeable and fluid, it can at least be maintained that contemplative practices enable us to explore and modify experience "in non-arbitrary ways" (Varela and Shear 1999, 13-14).

\section{Fourth Turning-A Way Forward?}

So, where does this leave us? From what has been said, there seem to be no insurmountable obstacles to the prospect of establishing cross-cultural cognitive (neuro)science. It is true that, presently, concrete results are scarce, but time and further research will tell, whether such collaboration is empirically fruitful, and therefore worth pursuing. In this respect, the in-principle, armchair objections must be regarded with suspicion, as they risk throwing out the baby with the bathwater: there is little doubt that the idea is beset by many (methodological, hermeneutical, etc.) problems, but this does not mean that its basic tenets are hopelessly flawed.

This brings us back to our initial discussion. It seems that the two lines of criticism that proponents of Buddhism-neuroscience collaboration must face, although very different on the surface, have one thing in common: they are both prescriptively restrictive, in that they are convinced of being able to authoritatively proclaim what Buddhism is (not), and what it is (not) capable of, in spite of any claims to the contrary from (at least some) Buddhist practitioners and/or sympathizers. "Rejectionists" posit rigid, impermeable classificatory categories (if A is a science, then A cannot be a religion, and vice versa), while "constructivists" deny the existence of any fixed categories, seeing the latter as nothing but temporary solidifications in the on-going flow of unbridled discursivity; but they both feel that theirs is the right, and only, way of conceiving Buddhism (even if, as in the second case, "conceiving" actually means "deconstructing"). Buddhism is either 
a full-blooded religion (which is basically synonymous with backwardness, superstition, fire-and-brimstone theology, etc.) or a bricolage of specific discursive histories clumsily lumped under a common concept; it is either a static, rigidly defined entity or a dynamic, kaleidoscopic non-entity.

The question ultimately boils down to how we conceive not only Buddhism but all systems that claim to be seeking (ab)solutions on the existential/experiential level. According to Payne, for example, we can approach Buddhist traditions in two ways: as "living traditions" that "develop in relation to the changing world within which they exist", or as "dead systems of religious doctrines" (Payne 2002,2). Both lines of criticism, although approaching the matter from different angles, seem to subscribe to the second view, while the proponents of Buddhism-(neuro)science dialogue, for the most part, opt for the first view, insisting that Buddhism's "theories and teachings must be brought into dialogue with contemporary thought" (ibid., 2). A "living tradition" in this sense would be a tradition that addresses certain existential needs in structurally similar ways, which means that it manifests itself through discursive frameworks (is there any other way?), but cannot be fully reduced to them. It is, in other words, dynamic, but not a non-entity. Lopez' critical remarks on the blunders surrounding the talk of "the abstract entity 'Buddhism', moving from culture to culture around the world and absorbing all that it encounters into itself" (Lopez 2008,34; my emphasis) is therefore correct, but beside the point. The main feature of a living tradition is precisely that it is not (merely) abstract, but relates (also, and predominantly) to lived experience: failing to find a common "theoretical core" therefore doesn't necessarily mean that Buddhism is nothing over and above the sum of its background sociocultural conditions.

And as long as any elements of this (existential/experiential) sort can be identified in Buddhism, the prospects of establishing cross-cultural cognitive (neuro)science are, at least prima facie, feasible; thus, "whatever value (a cross-cultural) model (might have) lies not in any claim to historical authenticity but, rather, in its claim to being empirically accurate and productive of future research" (Davis and Thompson 2012, 585). In an excellent paper on scientific studies of meditation, for example, Lutz et al. (2007) argue that, despite numerous metaphysical and interpretative differences, traditional descriptions of meditative practices agree on some important structural commonalities: (i) it is believed that each such practice induces a predictable experiential state; (ii) this experiential state is claimed to have a predictable effect on both body and mind; (iii) meditative practices are claimed to be gradual in that the capability of inducing the intended state is believed to improve over time, resulting in the acquisition of certain traits and/or the occurrence of certain events (cognitive, emotional or physical). Barring research of this nature on the ground of its being purely fictional and not having anything 
to do with Buddhism (what Buddhism, mind you?) seems patently absurd. The famous historian Daniel J. Boorstin once suggested that the major obstacle to discovery is not ignorance, but the "illusion of knowledge" (in Wallace 2003, 27) —an admonition some contemporary authors would do well to heed.

\section{References}

Block, Ned. 2008. "Consciousness and Cognitive Access." Proceedings of the Aristotelian Society 108 (3): 289-317.

Chalmers, David J. 1995. "Facing up the problem of consciousness." Journal of Consciousness Studies 2 (3): 200-19.

—.1997. "Moving Forward on the Problem of Consciousness." Journal of Consciousness Studies 4 (1): 3-46.

Davis, Jake H., and Evan Thompson. 2014. "From the Five Aggregates to Phenomenal Consciousness: Towards a Cross-Cultural Cognitive Science.” In A Companion to Buddhist Philosophy, edited by Steven M. Emmanuel, 585-97. London: John Wiley \& Sons.

Dennett, Daniel. 1991. Consciousness Explained. Boston: Little, Brown and Company. Federman, Asaf. 2011. "What Buddhism Taught Cognitive Science about Self,

Mind and Brain." Enrahonar: Quaderns de Filosofia 47: 39-62.

Forman, Robert K. C. 2007. "What Does Mysticism Have to Teach Us about Consciousness?” AntiMatters 1 (2): 71-89.

Froese, Tom. 2010. "From Cybernetics to Second-order Cybernetics: A Comparative Analysis of Their Central Ideas." Constructivist Foundations 5(2): 75-85.

Gallagher, Shaun. 2003. "Phenomenology and experimental design." Journal of Consciousness Studies 10 (9-10): 85-99.

Garfield, Jay L. 2011. "Ask Not What Buddhism Can Do for Cognitive Science, Ask What Cognitive Science Can Do for Buddhism.” Bulletin of Tibetology 47: 15-30.

Gould, Steven Jay. 1999. Rock of Ages: Science and Religion in the Fullness of Life. New York: Ballantine.

Hume, David. 1739. Treatise on Human Nature. London: John Noon. James, William. 1950. The Principles of Psychology. Vol. I \& II. New York: Dover. Lancaster, Brian Les. 2005. "Mysticism and Cognitive Neuroscience: A Partnership in the Quest for Consciousness." Conscienscias 2: 247-68. Levine, Joseph. 2002. "Materialism and qualia: Explanatory gap." In Philosophy of mind: Classical and contemporary readings, edited by David J. Chalmers, 354-61. New York: Oxford University Press. 
Lopez, Donald S. 2008. Buddhism E Science. Chicago and London: The University of Chicago Press.

Lutz, Antoine, John D. Dunne, and Richard J. Davidson. 2007. "Meditation and the Neuroscience of Consciousness: An Introduction." In Cambridge Handbook of Consciousness, edited by P. D. Zelazo, M. Moscovitch, E. Thompson, 497-549. Cambridge: Cambridge University Press.

Lynch, Zack. 2009. The Neuro Revolution: How Brain Science is Changing the World. New York: St. Martin's Press.

Metzinger, Thomas. 2003. On Being No One. Cambridge, London: The MIT Press. Nagel, Thomas. 1974. "What is it like to be a bat?" Philosophical Review 83(4): 435-50.

Payne, Richard K. 2002. "Buddhism and Cognitive Science: Contributions to an Enlarged Discourse." Pacific World: Journal of the Institute of Buddhist Studies 3 (4): 1-14.

Sharf, Robert H. 1995. "Buddhist Modernism and the Rhetoric of Meditative Experience." Numen 42: 229-83.

- 2000. "The Rhetoric of Experience and the Study of Religion." Journal of Consciousness Studies 7 (11-12): 267-87.

Shear, Jonathan, and Ron Jevning. 1999. "Pure Consciousness: Scientific Exploration of Meditation Techniques." In The View from Within: FirstPerson Approaches to the Study of Consciousness, Francisco J. Varela, and Jevning Shear, 189-209. Thorventon: Imprint Academic.

Thompson, Evan. 2005. "Empathy and Human Experience." In Science, Religion, and the Human Experience, edited by J. D. Proctor, 261-85. New York: Oxford University Press.

—. 2007. "Neurophenomenology and Contemplative Experience." In The Oxford Handbook of Science and Religion, edited by P. Clayton, 226-35. New York: Oxford University Press.

-. 2009. "Contemplative Neuroscience as an Approach to Volitional Consciousness." In Downward Causation and the Neurobiology of Free Will, edited by N. Murphy, G. F. R. Ellis, and T. O'Connor, 187-97. Dordrecht: Springer.

Varela, Francisco J., and Natalie Depraz. 2003. "Imagining: Embodiment, Phenomenology, and Transformation." In Buddhism and Science: Breaking New Ground, edited by Allan B. Wallace, 195-230. New York: Columbia Press.

Varela, Francisco J., and Jevning Shear. 1999. "First-Person Methodologies: What, Why, How?" In The View from Within: First-Person Approaches to the Study of Consciousness, edited by Francisco J. Varela, and Jevning Shear, 1-14. Thorverton: Imprint Academic. 
Varela, Francisco J. 1996. "Neurophenomenology: A Methodological Remedy for the Hard Problem." Journal of Consciousness Studies 3 (4): 330-49.

Varela, Francisco J., Evan Thompson, and Eleanor Rosch. 1991. The Embodied Mind: Cognitive Science and Human Experience. Cambridge, MA: MIT Press.

Vörös, Sebastjan. 2013. Podobe neupodobljivega: (Nevro)znanost, fenomenologija, mistika. Ljubljana: KUD Logos.

—. 2014. "The Uroboros of Consciousness: Between the Naturalisation of Phenomenology and the Phenomenologisation of Nature." Constructivist Foundations 10 (1): 96-104.

Wallace, Allan B. 1999. “The Buddhist Tradition of Samatha: Methods for Refining and Examining Consciousness." In The View from Within: FirstPerson Approaches to the Study of Consciousness, edited by Francisco J. Varela, and Jevning Shear, 175-87. Thorventon: Imprint Academic.

—. 2002. "A Science of Consciousness: Buddhism (1), the Modern West (0)." The Pacific World: Journal of the Institute of Buddhist Studies 3 (4): 15-31.

—- ed. 2003. "Introduction: Buddhism and Science - Breaking New Barriers." In Buddhism and Science: Breaking Nerw Ground, 1-29. New York: Columbia Press.

Wilson, Edward Osborne. 1998. Consilience: The Unity of Knowledge. New York: Knopf. 